University of Thi-Qar Journal Vol.10 No.1 Mar 2015

Web Site: https://jutq.utq.edu.iq/index.php/main Email: journal@jutq.utq.edu.iq

\title{
A Comparative Study of Superoxide Dismutase Purification from Red Blood Cells of Near Residents to Cellular Phone Base-Stations Antennas
}

\author{
https://doi.org/10.32792/utq/uti/vol10/1/7
}

\author{
Ali Haneen Ismeer \\ Department of Chemistry, College of Sciences, University of Thi-Qar \\ alihaneen77@gmail.com
}

\begin{abstract}
Superoxide dismutase (SOD) is the first line of defense against reactive oxygen species (ROS) such as the superoxide radical which is a toxic to living cells as it oxidizes and degrades biological molecules such as lipids and proteins. In the present study, SOD was purified from red blood cells (RBCs) of individuals who were living nearby the cellular phone base-station and others who living far from these stations. Over the last 10 years, there has been a wide spread in the use of cellular phones in Iraq, the communication system which can require hundreds of antennas in close proximity to the population with exposure to the radiation. The emitted radiation from these antennas may affect the biological systems. The aim of this work was to comprise the purification of SOD from RBCs of two individual groups. The first group (G1) was included individuals who reside near from mobile phone base-station, and the second group (G2) was included the individuals who inhabit far from these stations. We applied a simple and rapid procedure for the purification by ion exchange chromatography on diethylaminoethyl (DEAE)-Sepharose column. SOD was purified with a fold of purification of 20.6, yield of $47.5 \%$, SOD specific activity was 2948 (U/mg) for G1, while for the G2 the fold of purification was equal to 15.4 with a yield of $20.6 \%$ and $2143(\mathrm{U} / \mathrm{mg})$ as a specific activity of SOD. This procedure appears, therefore, to be a convenient and easily method for isolating this enzyme.
\end{abstract}

Key words: Superoxide dismutase, Ion-exchange chromatography, red blood cells.

\section{Introduction}

Superoxide dismutase (SOD) (E.C:1.15.1.1) is the first line of defense against reactive oxygen species (ROS), catalyzes the dismutation of the superoxide anion $\left(\mathrm{O}_{2}{ }^{-}\right)$ into hydrogen peroxide $\left(\mathrm{H}_{2} \mathrm{O}_{2}\right)$ [1]. Superoxide radical is a toxic to living cells as it oxidizes and degrades biological molecules such as lipids and proteins [2]. It is formed in cells as a result of both enzymatic and spontaneous oxidation reaction [3].The first study 


\section{University of Thi-Qar Journal Vol.10 No.1 Mar 2015}

Web Site: https://jutq.utq.edu.iq/index.php/main Email: journal@jutq.utq.edu.iq

concerning SOD was carried out by Mann and Keilin in 1938 [4]. SODs are classified into four groups depending on their metal cofactors: MnSOD, Cu-ZnSOD, FeSOD and NiSOD [5]. The Cu-ZnSODs are typically found in the cytosol of eukaryotes [6]. Marklund in 1982 purified extracellular SOD (EC-SOD) from human lung and found this enzyme is $\mathrm{Cu}-\mathrm{Zn}$ SOD [7]. Cu-Zn SOD of human red blood cells has a molecular mass of 32000 and consists of two identical subunits each containing one $\mathrm{Cu}^{2+}$ and one $\mathrm{Zn}^{2+}$ in the active site [8].

Red blood cells (RBCs) are unique, highly specialized and the most abundant cells in the human organism. Although their primary function is transportation of the respiratory gases, $\mathrm{O}_{2}$ and $\mathrm{CO}_{2}$, between lungs and tissues, these circulatory cells are equipped with effective anti-oxidative systems that make them mobile free radical scavengers, providing antioxidant protection not only to themselves but also to other tissues and organs in the body $[9,10]$.

Recently, many studies had reported that emitted radiation from cellular phones stations antennas affect the biological systems by increasing free radicals that enhance lipid peroxidation, change the antioxidative activities, protein and DNA damage [11-13]. We have previously determined non-isolated SOD activity in RBCs of individuals exposed to radiation emitted from cellular phone stations [14].

The human $\mathrm{RBC}$ is a rich raw material for the purification of SOD and the medical uses of the isolated or coupled antioxidant enzymes SOD has been studied in relation to the treatment of many diseases [15].

The aim of this work was to comprise the purification of SOD from RBCs of two individual groups by using simple and rapid procedure for the purification by combined extraction by organic solvent and ion exchange chromatography on diethylaminoethyl (DEAE)-Sepharose column. 


\section{Materials and Methods}

\section{1 Chemicals}

All laboratory chemicals and reagents in this work were of analar grade and imported from BDH Co. and SIGMA Co., Nitroblutetrazolium (NBT) from Fluka Co.

\subsection{Subjects}

Samples were collected from appearent healthy, male volunteers live in Baghdad city. They were divided to two groups; the first was included individuals whom inhabit around cellular phone base-station (within $100 \mathrm{~m}$ ) at least for three years while the second group consisted of individuals whom inhabit faraway from base- station as a control group. All individuals ages were from 20-30 years.

\subsection{Blood Collection and Red Blood Cells Separation}

A volume of $2.5 \mathrm{ml}$ of venous blood had been collected into heparinized tubes from all volunteers then centrifuged for 10 minutes at $3000 \mathrm{~g}$. The plasma and buffy coat were aspirated carefully by Pasture pipette and the red blood cells (RBCs)were washed three times with $0.9 \% \mathrm{NaCl}$ and stored at $-20^{\circ} \mathrm{C}$ prior to use [16].

\subsection{Isolation of SOD}

Isolation and purification of SOD from RBCs was carried out according to the Djalali et al method with slight modification [15].

A volume of pooled RBCs was haemolysed by addition of 3 volume of cold distilled water at $4{ }^{\circ} \mathrm{C}$ while ethanol was added with adequate stirring to a final concentration of $25 \%(\mathrm{v} / \mathrm{v})$. Cold chloroform was then added to the mixture to a concentration of $12 \%(\mathrm{v} / \mathrm{v})$. Stirring was continued for $30 \mathrm{~min}$ during which time the hemoglobin was rendered insoluble. The supernatant contained essentially all of the SOD activity and additional solution in the precipitate recovered by centrifugation for $10 \mathrm{~min}$ at $2000 \mathrm{~g}$. The resulting supernatant was tested for SOD activity and total protein (as describe later in 2.5 and 2.6 respectively) and allowed to warm at room temperature and solid $\mathrm{K}_{2} \mathrm{HPO}_{4}(300 \mathrm{~g} / \mathrm{l})$ was added resulting in the separation of two liquid phases. The denser phase was essentially aqueous and contained most of the salts, the lighter phase was ethanol and contained SOD and little salts. The upper phase was collected and centrifuged then a volume of supernatant was tested for SOD activity and total protein while other volume was processed exchange chromatography column.

\subsection{Ion Exchange Chromatography}

Ion exchange chromatography was used to separate SOD from human RBCs according to the Gartner et al [18] with slight modification on a column $(10 \times 2 \mathrm{~cm})$ of 
diethylaminoethyl (DEAE)-Sepharose CL-6B. DEAE-Sepharose was equilibrated with $2.5 \mathrm{mM}$ phosphate buffer saline (PBS) $\mathrm{pH} 7.4$ at a flow rate of $12 \mathrm{ml} / \mathrm{h}$. A volume of $5 \mathrm{ml}$ of supernatant obtained in above section applied onto the top surface of gel and left in contact with gel for 2 hours. The DEAE-Sepharose was washed with equilibration buffer to remove all nonbinding proteins. SOD was eluted with $50 \mathrm{mM}$ PBS and the eluent was collected in $1.5 \mathrm{ml}$ fractions. These fractions were assayed for SOD activity and total protein as describe later (in 2.5 and 2.6 respectively).

\subsection{Determination of SOD Activity}

Superoxide dismutase (SOD) activity was determined in method based on the reduction of nitro blue tetrazoluim (NBT) which causes an increase in absorbance at $560 \mathrm{~nm}$. The sensitizing dye (riboflavin) is readily reduced by illumination in the presence of oxidizable compounds. The photo reduced dyes then react with $\mathrm{O}_{2}$ to generate $\mathrm{O}_{2}^{-}$, which can be detected by its ability to reduce NBT; the inhibition $\%$ of this reaction (one unit of SOD is that which causes a $50 \%$ inhibition of the rate of NBT reduction under the condition of assay. Enzyme activity was expressed as SOD $\mathrm{U} / \mathrm{gm}$ of protein [16].

\subsection{Total Protein Concentration}

Protein concentration was determined by the method described by Lowry et al [19] using bovine serum albumin as standard for all samples.

\section{Results and Discussion}

Superoxide dismutase (SOD) was purified from RBCs of the two studied groups. Purification tables were constructed using the data obtained after each purification step for samples of group 1 and group 2 (table 1 and table 2 respectively).

Table 1: The Purification steps of RBC SOD of the individuals nearby cellular phone stations. (Group 1). 
Table 2: The Purification steps of RBC SOD of the individuals faraway cellular

\begin{tabular}{|c|c|c|c|c|c|c|c|}
\hline $\begin{array}{c}\text { Purification } \\
\text { steps }\end{array}$ & $\begin{array}{c}\text { Sample } \\
\text { volume } \\
(\mathrm{ml})\end{array}$ & $\begin{array}{c}\text { Protein } \\
\text { Conc. } \\
(\mathrm{mg} / \mathrm{ml})\end{array}$ & $\begin{array}{c}\text { Total } \\
\text { protein } \\
(\mathrm{mg})\end{array}$ & $\begin{array}{c}\text { Total } \\
\text { enzyme } \\
\text { activity } \\
(\mathrm{U})\end{array}$ & $\begin{array}{c}\text { Specific } \\
\text { activity } \\
(\mathrm{U} / \mathrm{mg})\end{array}$ & $\begin{array}{c}\text { Yield } \\
\%\end{array}$ & $\begin{array}{c}\text { Purification } \\
\text { fold }\end{array}$ \\
\hline $\begin{array}{c}\text { Ethanol- } \\
\text { chloroform } \\
\text { extract }\end{array}$ & 12.9 & 0.243 & 3.134 & 180.6 & 57.62 & 100 & 1 \\
\hline $\begin{array}{c}\text { After } \\
\text { K2HPO4 }\end{array}$ & 5.4 & 0.086 & 0.464 & 66.4 & 143.14 & 36.7 & 2.4 \\
\hline $\begin{array}{c}\text { DEAE- } \\
\text { Sepharose } \\
\text { CL-6B } \\
\text { elution }\end{array}$ & 9 & 0.0012 & 0.01 & 31.5 & 2948 & 47.5 & 20.6 \\
\hline
\end{tabular}

phone stations. (Group 2).

Hemoglobin is almost completely removed when using of an ethanol-

\begin{tabular}{|c|c|c|c|c|c|c|c|}
\hline $\begin{array}{c}\text { Purification } \\
\text { steps }\end{array}$ & $\begin{array}{c}\text { Sample } \\
\text { volume } \\
\text { (ml) }\end{array}$ & $\begin{array}{c}\text { Protein } \\
\text { Conc. } \\
(\mathrm{mg} / \mathrm{ml})\end{array}$ & $\begin{array}{c}\text { Total } \\
\text { protein } \\
(\mathrm{mg})\end{array}$ & $\begin{array}{c}\text { Total } \\
\text { enzyme } \\
\text { activity } \\
\text { (U) }\end{array}$ & $\begin{array}{c}\text { Specific } \\
\text { activity } \\
(\mathrm{U} / \mathrm{mg})\end{array}$ & $\begin{array}{c}\text { Yield } \\
\%\end{array}$ & $\begin{array}{c}\text { Purification } \\
\text { fold }\end{array}$ \\
\hline $\begin{array}{c}\text { Ethanol- } \\
\text { chloroform } \\
\text { extract }\end{array}$ & 13 & 0.276 & 3.588 & 224.9 & 62.68 & 100 & 1 \\
\hline $\begin{array}{c}\text { After } \\
\text { K}_{2} \text { HPO }\end{array}$ & 6 & 0.105 & 0.23 & 87.22 & 138.44 & 38.7 & 2.2 \\
\hline $\begin{array}{c}\text { DEAE- } \\
\text { Sepharose } \\
\text { CL-6B } \\
\text { elution }\end{array}$ & 6 & 0.0384 & 0.0084 & 18 & 2143 & 20.6 & 15.4 \\
\hline
\end{tabular}

chloroform mixture in early stages of purification of erythrocytes $\mathrm{Cu}-\mathrm{Zn} \mathrm{SOD}$, the step which facilitates future purification [20]. Hemoglobin could inhibit the reaction of superoxide radicals with NBT and interfered with the assay if it was found [21]. Another study observed that exposure treatment with ethanol-chloroform leads to an increase in the degree of heterogeneity [22]. $\mathrm{K}_{2} \mathrm{HPO}_{4}$ used to increase the $\mathrm{pH}$ of the solution and since this $\mathrm{pH}$ is higher than the $\mathrm{pH}$ of SOD where only contaminant proteins are precipitated [21]. It appears from the table 1and table 2, that SOD was purified by this step with a fold of purification of 2.4 and a yield of $36.7 \%$ for G 1 , while the fold of purification is equal to 2.2 with a yield of $40 \%$ for the $\mathrm{G} 2$.

There are some of attractive features for the ion exchange chromatography using DEAE-Sepharose CL-6B as ion exchanger. It has a high ability to separate, high 
capacity, so easy prepare, therefore can be activated again, and used more than once [23].

In ion exchange chromatography, proteins that interact weakly with the resins, for example a weak positively charged protein passed over resin modified with a negatively charged group, are eluted out in a low-salt buffer. On the other hand, proteins that interact strongly required more salt to be eluted. Proteins with very similar charge characteristics can be separated into different fractions as they are eluted from the column by increasing the concentration of salt in elution buffer [24].

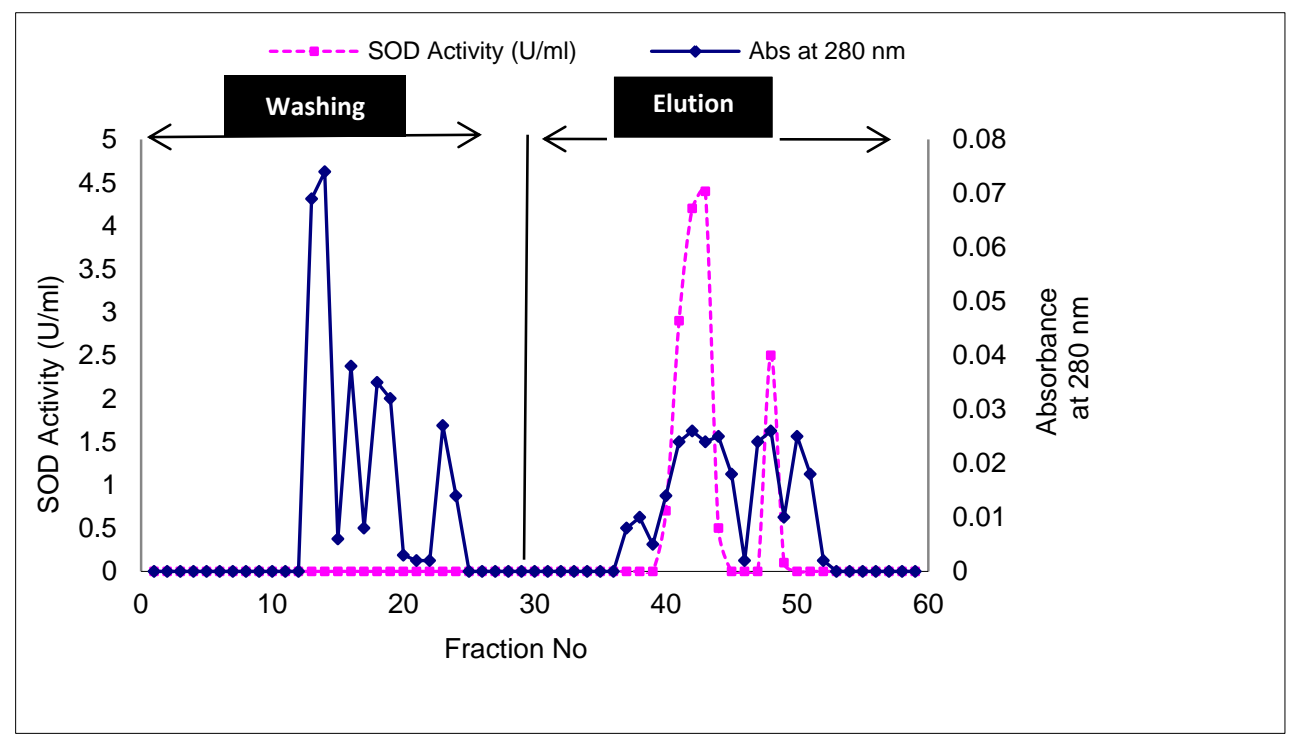

Fig. 1: Chromatogram of fractions of SOD in samples of individuals nearby from cellular phone base-stations (G1).

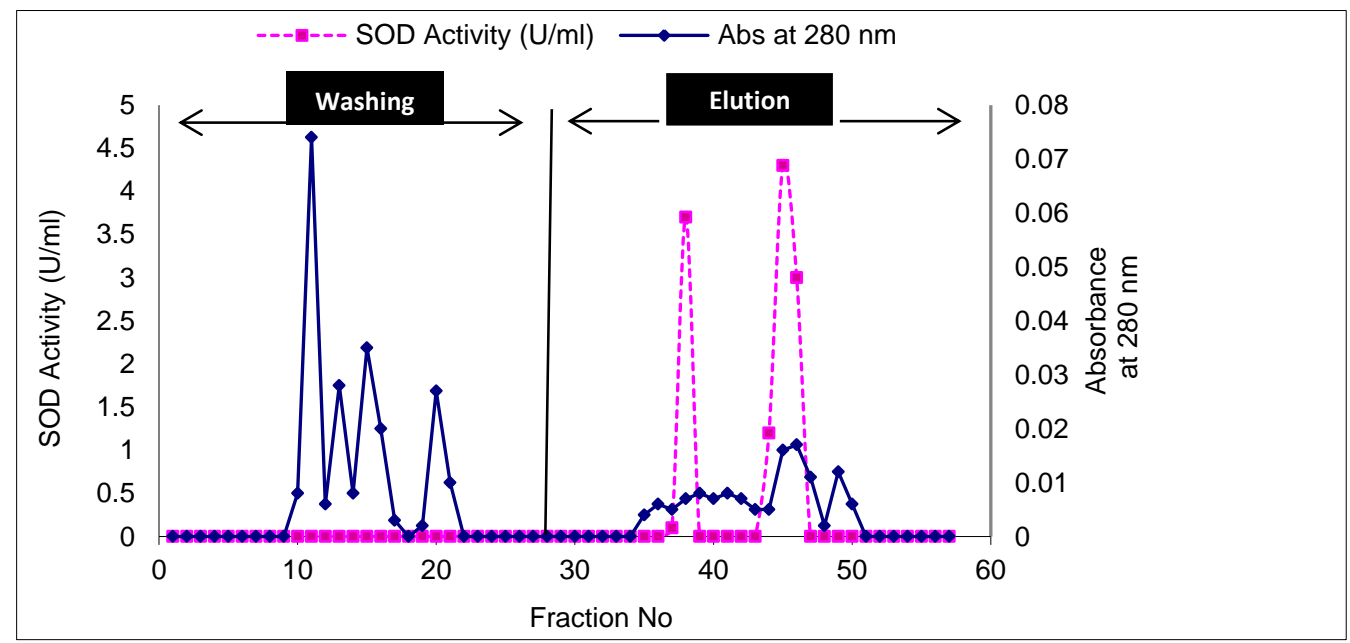

Fig. 2: Chromatogram of fractions of SOD in samples of individuals faraway from cellular phone base-stations (G2).

The presence of the protein in the washing fractions was detected by measurement of the absorbance at $\lambda=280 \mathrm{~nm}$, when the absorbance reached base line, 
the gradient elution was carried out using phosphate buffer $50 \mathrm{mM}, \mathrm{pH}$ 7.4. The eluted fraction also detected at $280 \mathrm{~nm}$ presented an SOD activity (Fig. 1 \& Fig. 2). Superoxide dismutase activity was measured in all washing and elution fractions, as well as protein concentration as described in 2.5 and 2.6 respectively.

From the obtained results shown in figure 1and figure 2, it is clear that washing fractions did not have any activity for SOD, while the activity appeared in fractions collected in the elution step. The appearance of activity in the eluted fractions indicated that SOD carries a negative net charge at the used conditions.

It appears from the table 1and table 2, that SOD was purified by this step with a fold of purification of 20.6 and a yield of $47.5 \%$ for $\mathrm{G} 1$, while for the $\mathrm{G} 2$ the fold of purification is equal to 15.4 with a yield of $20.6 \%$.

The results in the table $1 \& 2$ demonstrated there are increasing in the fold purification in G1 more than in G2. This can be explained, such as the acidic protein which has a negative net charge is usually adsorbed with the positive groups of the ion exchange column in the present study. These differences may be due to presence of different quantity of negatively charged protein in each group. Therefore samples of $\mathrm{G} 1$ may contain an amount of total proteins that have a negative net charge less than which are present in $\mathrm{G} 2$. This will lead to a competition of these proteins with SOD to bind the column.

Al-Gazaly found that SOD from human RBCs (control) was purified using ionexchange chromatography (IEC) 10671.4 fold with a yield of $73.3 \%$ and its specific activity was $2955.98 \mathrm{U} / \mathrm{mg}$ of protein, while SOD from chronic children diarrhea was purified 16256.67 fold with a yield of 83.469 and its specific activity was 6502.67 $\mathrm{U} / \mathrm{ml}$ of protein [21]. While Karadag and Bilgin who purified SOD from human RBCs, reported 20.2 fold with a yield of $55.1 \%$ and specific activity was $155.41 \mathrm{U} / \mathrm{mg}$ of protein after using (IEC) method [4].

Djalai et al used a new method for purification of SOD from human RBCs and they found the following data: 7606 fold with a yield of $73 \%$ and specific activity was 2285.6 U/mg of protein [15]. Weselake et al isolated CuZnSOD from human RBCs hemolysate by DEAE-Sepharose and copper chelate affinity chromatography. They reported 58\% yield and 2000 fold purification and specific activity of $3800 \mathrm{U} / \mathrm{mg}$ [25].

Mavi et al reached to $12 \%$ yield, 837 -fold purification, and specific activity of $1085 \mathrm{U} / \mathrm{mg}$ when they purified CuZnSOD from human RBCs by DEAE-cellulose and copper-chelate affinity chromatography [26]. On the other hand, Aydemir etal purified CuZnSOD from chicken RBCs by DEAE-cellulose and Sephadex G-100 gel columns and they reached to specific activity of $8480 \mathrm{U} / \mathrm{mg}$, corresponding to 508fold purification [27]. Also Ozturk Urek et al isolated, purified CuZnSOD from chicken liver by DEAE-IEC and Sephadex G-75 gel filtration chromatography [28]. 
They reached to $7.3 \%$ yield corresponding to 285.8 -fold purification and specific activity of $4818.2 \mathrm{U} / \mathrm{mg}$. Inouye et al purified CuZnSOD from bovine RBCs with acetone precipitation and high performance ion exchanger, TSK-GEL DEAE-5PW. They reported that the specific activity of CuZnSOD was $3800 \mathrm{U} / \mathrm{mg}$ protein [29].

\section{References}

1-Chun P. Q., Zhi R. X., Guan J. L., Chun L., Yang L., Zhi G. W. and Gui F. L. [2010]:Differential Expression of Copper-Zinc Superoxide Dismutase Gene of Polygonum sibiricum Leaves, Stems and Underground Stems, Subjected to High-Salt Stress. Int. J. Mol. Sci. 11, 5234-5245.

2-Bayani Uttara [2009]: Oxidative Stress and Neurodegenerative Diseases: A Review of Upstream and Downstream Antioxidant Therapeutic Options. Curr Neuropharmacol, 7(1):65-74.

3- Desai N, [2009]: Pathophysiology of cell phone radiation: oxidative stress and carcinogenesis with focus on male reproductive system. Rep. Biol. and Endo., 7,114.

4- Karadag, [2010]: Purification of Copper - Zinc superoxide dismutase from human erythrocytes and partial characterization. Biotechnol. \& Biotechnol,24(1):1653-1656.

5- Balakrishnan P., Jagadeesan P., Raman T. Dhanalakshmi, Thangaraj S., Lakshmanan U., Dharmar P. and Gopalakrishnan S. [2007]: Comparative analysis of cyanobacterial superoxide dismutases to discriminate canonical forms. BMC Genomics, 8:435.

6- Aydemir, T., R. Ozturk, L. A. Bozkaya and L. Tarhan. [2000]: Effects of antioxidant vitamins A, C, E and trace elements $\mathrm{Cu}$, Se on CuZn SOD, GSH-Px, CAT and LPO levels in chicken erythrocytes. Cell Biochem. Funct. 18:109-115.

7- Marklund SL, Holme E, Hellner L.[ 1982]: Superoxide dismutase in extracellular fluids. Clin Chim Acta;126(1):41-51.

8-Mrowicka M1, Garncarek P, Miller E, Kedziora J, Smigielski J, Malinowska K, Mrowicki J. [2010]: Effect of melatonin on activity of superoxide dismutase (CuZn-SOD) in erythrocytes of patients during short- and long-term hypokinesis. Wiad Lek;63(1):3-9.

9- Kanti B P. and Syed I. R.[2011]: Biomarkers of oxidative stress in red blood cells. Biomed Pap Med Fac Univ Palacky Olomouc Czech Repub.; 155:XX. DOI 10.5507/bp.2011.027

10- Richard J. Bloomer, Robert E. Canale, Cameron G.McCarthy, and Tyler M. Farney. [2012]: Impact of oral ubiquinol on blood oxidative stress and exercise performance. Oxidative Medicine and Cellular Longevity.Volume 2012, Article ID 465020, 10 pages.

11- Jajte J., Grzegorczyk J., Zmyslony M., Rajkowska E. [2002]: Effect of 7 mT static magnetic field and iron ions on rat lymphocytes: apoptosis, necrosis and free radical processes. Bioelectrochemistry 57, 107-111

12-Dasdage S., Bilgin H., Akdag M., Celik H. and Aksen F. [2008]: Effect of long term mobile phone exposure on oxidative- antioxidative processes and nitric oxide in rats. Biotechnol. \& Biotechnol.:992-997.

13-Achudume A., Onibere B., and Aina F.[2009]: Bioeffect of electromagnetic base station on glutathione reductase, lipid peroxidation and total cholesterol in different tissues of Wistar rats. Biol. and Med., 1(3):33-38

15-Djalali M, Abtahi H, Sadeghi MR, Negahdar M, Layegh H, Farzamie B, Fatehi F.: [2005]: A new method for the purification of cu-zn superoxide dismutase from human erythrocytes. Iranian J Publ Health, 34(4):58-66. 
14- Hasan H. and Issmer A. [2014]: Effect of emitted radiation from mobile phones and its base station antennas on some biochemical parameters in human red blood cells. Int. J. Sci. And Engin. Res., 5(3): 965-970.

16- Winterboum C., Hawkins R., Brian M., and Carrell R [1975]: The estimation of red cell SOD activity. J. Lab. And Clin. Med., 8(2):337-341.

18- Gärtner A, Weser U [1983]: Erythrocuprein (Cu2Zn2 superoxide dismutase) is the major copper protein of the red blood cell. FEBS Lett, 155(1):15-18.

19-Lowry O., Roserbongh N., and Farr N. [1951]. Protein measurement with the Folin phenol reagent. J Biol Chem. 193:265-275.

20- Michalski WP [1996]. Chromatographic and electrophoretic methods for analysis of superoxide dismutases. J Chromatogr B Biomed Appl. 684 (1-2):59-75.

21- Al-Gazally M. O. [2007]: Serum antioxidant enzymes and purification of blood cells cuzn superoxide dismutase in chronic childhood diarrhea. Sci. J. Kerb. Uni., 5(1):39-51.

22- Stancell MJ. And Deutsch HF. [1965]: J Biol Chem; 240(11):4306-4311.

23- Scopes R.K. [1987]: Protein purification principles and practice, 2nd. Springer relag, Inc. London.

24- Watson J. D., Baker T. A., Bell S. P., Gann A., Lecine M., and Losick R.[2004]: Molecular Biology of the Gene, Benjamin Cummings, San Francisco, Calif, USA, 5th edition.

25-Weselake R.J., Chesney S.L., Petkau A. and Friesen A.D. [1986]: Purification of human copper, zinc superoxide dismutase by copper chelate affinity chromatography. Anal. Biochem., 155(1), 193197.

26-Mavi A., Küfrevioğlu Ö.İ., Yildirim A. [2006]: Effects of some drugs on purified human erythrocyte CuZnSOD and in vitro inhibitiory effect of 5-fluorouracil on leukocyte total SOD activity. J Enzym Inhib Med Ch., 21(2), 235-239.

27-Aydemir T., Tarhan L. [2001]: Purification and partialy characterization of superoxide dismutase from chicken erythrocytes. Turk. J. Chem., 25, 451- 459.

28-Ozturk Urek R., Tarhan L. [2001]: Ozturk Urek R., Tarhan L. [2001]: Purification and characterization of superoxide dismutase from chicken liver. Comp. Biochem. Phys. B Biochem. Mol. Biol, 128, 205-212.

29-Inouye K., Nakamura K., Mitoma Y., Matsumoto M., Igarashi T. [1985]: Application of a new ion exchanger TSK-Gel DEAE-5PW, to the purification of CuZn-superoxide dismutase of bovine erythrocytes. J. Chromatogr., 327, 301-311.
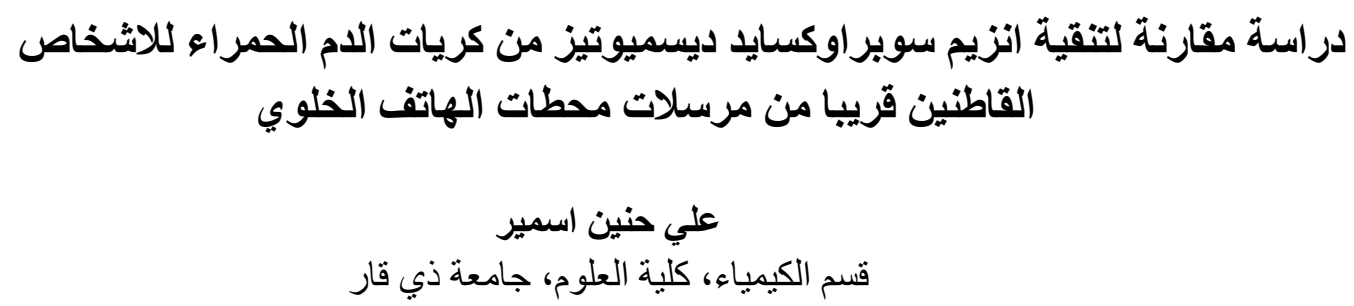

الخلاصة

يعتبر انزيم سوبراوكسايد ديسميوتيز خط الدفاع الاول ضد الاصناف الاوكسيجينية الفعالة مثل جذر الترات

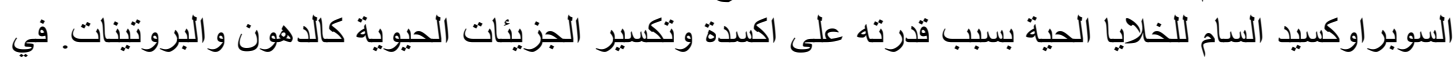

هذه الدراسة نقي انزيم انزيم سوبر اوكسايد ديسميوتيز من كريات الدم الحمراء للاشخاص الساكنين بجوار 


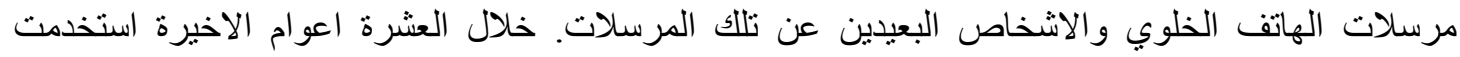

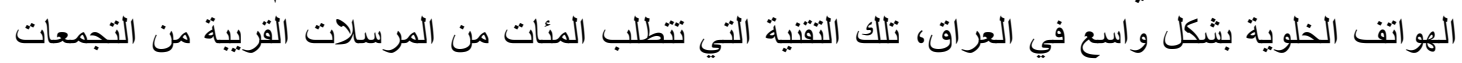

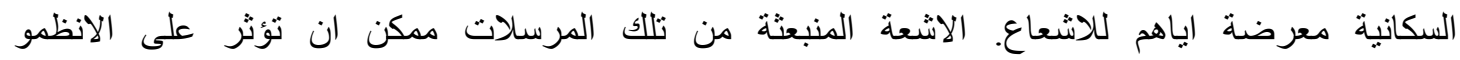

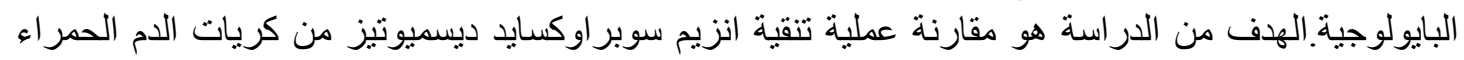

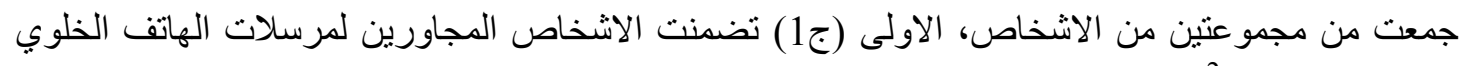

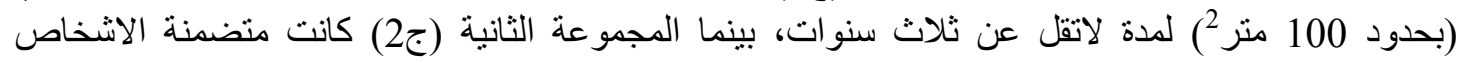

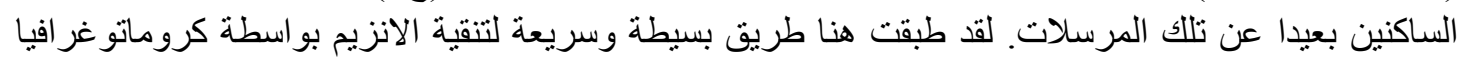

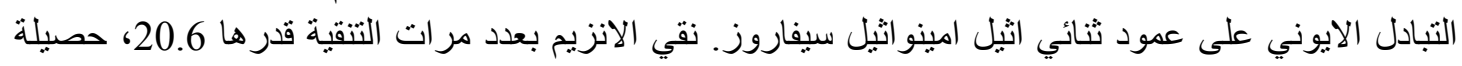

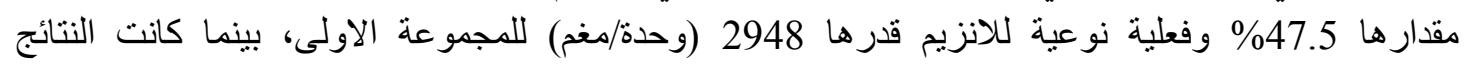

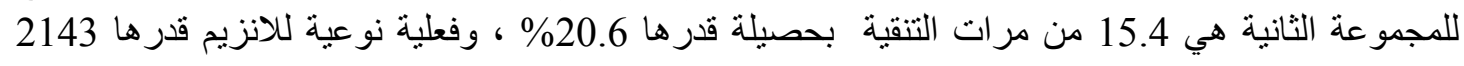
(وحدة/مغم). (لمعن. 